\title{
Saint Paul: Apostle of freedom in Christ
}

\author{
Petros VAssiliadis \\ Professor Emeritus of the Department of Theology of the Aristotle, \\ University of Thessaloniki \\ GRECEE \\ E-mail: pv@theo.auth.gr
}

\begin{abstract}
Many scholars in modernity have accused Saint Paul either for an unrestricted obedience to civil authorities (Rom 13), or for surrendering the divine gift of freedom and human dignity and accepting the status of slavery (1 Cor 7:21; Phlm), or for implying the subordination of women (1 Cor 14:34ff.; Eph 5:22; Col 3:18; etc.). I am referring of course to the well known household codes (Haustafeln, Col 3:18ff. and parallels). It was mainly these cases that gave rise to the criticism that Paul (or the Pauline school) did not resist with all his power as he should to the socio-political status quo of his time, and that he and his school, and Christianity thereafter, tolerated unjust social institutions and structures.
\end{abstract}

Keywords: Saint Paul; man; freedom; Christianism; social transformation;

\section{INTRODUCTION}

Saint Paul the Apostle is the first and greatest Christian theologian. He is the only one who clearly speaks to us from the first generation of Christianity with his own voice and the first Christian we know of who wrestled at length and to good effect with a variety of theological and ethical issues. One such issue is the concept of freedom, and one can justifiably call him "the Apostle of Freedom", taking into account that phrases like "For freedom Christ has set us free" (Gal 5:1), "the freedom we have in Christ Jesus" (Gal 2:4), or "the creation itself will be set free from its bondage to decay and will obtain the freedom of the glory of the children of God" (Rom 8:21), all come from his undisputed and by all means authentic letters. These statements and his letters in general quickly came to be recognized as of continuing authority for the Church up to the present era. And as part of the NT canon they have served to define Christian theology as no other set of documents has. This last point remains true, even when later writers (e.g. the Fathers in the Golden age) have been more determinative, since they all acknowledged the prior authority of Paul.

Saint Paul's letters, therefore, contain the first elaboration, though a sketchy one, of an understanding of Christian faith as freedom. Nevertheless, Saint Paul's conception of freedom has for generations been discussed within framework of, and for some in opposition to, the Jewish Law; consequently freedom is normally conceived of in relation to sin and death: in other words freedom is almost exclusively understood as freedom from the law, freedom from sin, and freedom from death. The analysis of the subject in the well-known TDNT by H. Schlier ${ }^{1}$ is largely ${ }^{2}$ responsible for this tendency, at least in recent biblical

${ }^{1}$ H. Schlier, «EXev6epia etc. ", TDNT vol. 2 pp. 496-502. 
scholarship. Based on a very surfaced and not a thorough examination of some NT data it was suggested that in the early Christian tradition a holistic understanding of freedom (i.e. including liberation) was not decisive for salvation. The only thorough treatment on the subject early in the '70s by an Orthodox scholar, the late colleague of mine Vassilios Stoyannos, was pursued on the same track, although he tried to underline some ecclesiological (and pneumatological), and therefore social, characteristics of freedom ${ }^{3}$.

The obvious question, therefore, of all unbiased students of the Bible, who are accustomed with the undisputed connection in the O.T. between freedom and liberation, is how a Jew, admittedly follower of his own traditions, could have completely despised the Jewish Law, and in addition internalize the basic story of the Shema. More and more biblical theologians nowadays realize that the above mentioned threefold schema is based not on a thorough examination of the proto-Pauline relevant passages, but on the assumption that law, sin, and death, being undoubtedly central entities in Saint Paul's thought, must have naturally influenced also his understanding of freedom.

This conventional treatment of the Pauline theology was the result of the antithesis between Law and Gospel, which had been for centuries the effective key for Christian theology at large ${ }^{4}$. For some scholars, ${ }^{5}$ this antithesis was a result of Paul's doctrine of justification by faith (Gospel) defined in opposition to justification by the works of the Jewish Law. Inevitably the antithesis between Christianity (Gospel) and Judaism (Law) came into the fore. Recent biblical scholarship, however, has convincingly demonstrated that this view owed more to the Reformation polemics than to a critical study of the Judaism and its canonical and extracanonical texts. Many scholars nowadays underline the real character of Judaism in the early Christian period, and Saint Paul's more positive statements about the law. Critical here has been also the recognition that Paul's conversion was in fact a prophetic calling similar to the calling of the Old Testament Prophets, or at least was not a conversion from first century "Judaism" as we today would define the term. Rather it was a conversion within Judaism. Paul did not think of himself as an apostate, but rather as carrying forward Israel's task to be a blessing to the nations and a light to the Gentiles ${ }^{6}$.

As a consequence Christianity is how defined not in opposition to Israel but by reference to its heritage and missionary task. In addition, today a refreshed reading of Rom. 9-11 has helped scholars to underline that Paul's hope was not for a Christianity freed from the Mosaic Law and distinct from Israel, but for an Israel defined by the grace and call of God within which Gentiles had an integral place.

It is not, therefore, only this "new perspective" in Pauline theology that requires a new approach to Saint Paul's understanding of freedom. The Pauline texts on freedom themselves also disclose a different picture. Modern and post-modern critical challenges to Saint Paul's de-radicalizing Jesus of Nazareth's teaching have also provided further elements

\footnotetext{
${ }^{2}$ Largely but not exclusively; see R. Bultmann, Theology of the New Testament. 2 vols. Trans. K. Grobel, New York and London 1955, esp. vol 1, pp. 330-52.

${ }^{3}$ Eleutheria, Thessaloniki 1973.

${ }^{4}$ Cf. K. Stendahl, Paul among Jews and Gentiles, Philadelphia: Fortress, 1976.

5 J. D. G. Dunn, The Theology of Paul the Apostle, Edinburgh: T. \& T. Clark, 1997, Grand Rapids: Eerdmans, 1998.

${ }^{6}$ More on this in A. F. Segal, Paul the Convert: The Apostolate and Apostasy of Saul the Pharisee, New Haven: Yale University Press, 1990.
} 
for such reconsideration ${ }^{7}$. Finally, the contribution some socio-anthropological studies have made in the N.T. field enhanced our understanding of the origins of Christianity in general and of freedom in particular. To these two approaches I will limit my presentation.

\section{A LITERARY AND RELIGIO-HISTORICAL APPROACH}

The Pauline passages that deal with freedom are worth considering in detail, for Paul is by far the most vocal advocate of freedom in the entire Bible. It is quite characteristic that almost all usages of the term eleutheria and its cognates (eleutheros, eleutheroun) in the N.T. occur in the authentic proto-Pauline epistles (26 altogether and only few outside them). Before analysing them, however, we must briefly refer to the O.T. and the Hellenistic background.

\section{The Old Testament background}

In the O.T. freedom is almost exclusively understood only in its social dimension,

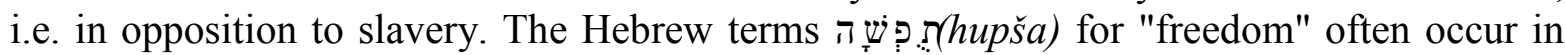
discussions of slavery and manumission. In these texts, hopši (free) is mainly used to designate someone merely freed from slavery. Though the redemption of Israel from slavery in Egypt is cited within the institution of Jubilee in support of the manumission of all Hebrew slaves every 7 th year (Deut 15:15), the O.T. does not develop a theology of freedom on the basis of the Exodus. In the book of Leviticus Israel was ransomed in order to be God's servants (Lev 25:42; cf. Deut 6:20-25). In sum, the language used to describe this event is primarily that of "redemption", not of "freedom." Only in the description of Jubilee, the year of "freedom", are we encountered with a real conception of freedom (Lev 25:10). This idea was theologically developed in Trito-Isaiah (Is 61:1), the passage on which Jesus of Nazareth has based his programmatic proclamation (Lk 4:16ff). We shall come later on this.

\section{The Greek, Hellenism and Roman Background}

In contrast to the O.T. Semitic tradition the Greek term eleutheria is first connected with the Greek resistance to the Persian Empire. Herodotus e.g. understood the Persian War as a defense of freedom and law against despotism. Eleutheria and libertas (Latin "freedom") were later developed in the Greek and Roman world. One standard definition of "freedom", at the latest since the time of Aristotle, was "doing whatever one wants" (to ho ti an bouletai tis poiein, repeated in Latin by Cicero ${ }^{8}$.

Greeks and Romans were of course aware that such a definition might lead to conflicts with the law. Stoic philosophers resolved the debate by asserting that since the law (of nature) is good and since no one desires to do what is bad, the only person who is truly free and does what he/she wants is the one who does what is good and thus follows the law 9 . Nevertheless, even this clarification did not put an end to the discussions and later the Cynics advanced the theory that the true law can be recognized only by the rugged individual in a struggle against vulgar opinions (including laws established merely by humans). This theory coincided with the rise of the oecumene, in place of the polls (city), as the framework for

\footnotetext{
${ }^{7}$ See among many H. D. Betz, Paul's Concept of Freedom in the Context of Hellenistic Discussions about the Possibilities of Human Freedom. Protocol Series of the Colloquies of the Center for Hermeneutical Studies in Hellenistic and Modern Culture 26. Berkeley 1977.

${ }^{8}$ Cicero Off. 1.70; Epict. Diss. 4.1.1; Dio Chrysostom, Orla 14. 13, 17 etc.

${ }^{9}$ See, e.g. Cicero Par ad. 34 and Epict. Diss. 4.1.1-5, 158.
} 
human life ${ }^{10}$. As a consequence a notion of an internal, individualized freedom started to be established in the Hellenistic age.

It is important at this stage to mention that in Greek classical antiquity a connection between freedom and God is clearly established, and the term eleutherios (Gk "liberating") became a particularly popular epithet of the gods.

\section{The Proto-Pauline evidence}

I will try to examine the literary evidence of the Pauline usage of eleutheria starting from the earlier evidence. The argument is not affected even if one takes Galatians as written earlier than the letters to the Corinthians.

a. Freedom in Christian literature is first mentioned in 1 Cor 7:22, in a wordplay in which Paul describes the Christian slave as a freedman of the Lord and the Christian freeman as a slave of Christ (whoever was called in the Lord as a slave is a freed person belonging to the Lord, just as whoever was free when called is a slave of Christ"). No matter how one interprets the crux interpretum ("mallon de chresai") in 1 Cor 7:21 ("make use of your present condition now more than ever"; or "avail yourself of the opportunity") as an answer to the rhetorical question "even if you can gain your freedom ", the dialectic employed here to comfort the Christian slave is strongly reminiscent of a broad spectrum of Hellenistic statements and discussions that dismissed external social status as decisive for true (internal) freedom $^{11}$. What Paul actually does here is that he introduced a Christological dimension. Christ is the liberator of Christians from slavery to a third party thus acting as the slave's patron. It was for this reason that Paul uses both for himself and for all Christians the epithet doulos Christou, meaning denial of being slave to any other force.

In sum, when Paul speaks of internal freedom, he clearly employs the great Hellenistic tradition concerning freedom. Parallel to Paul's statement "Christ is the liberator

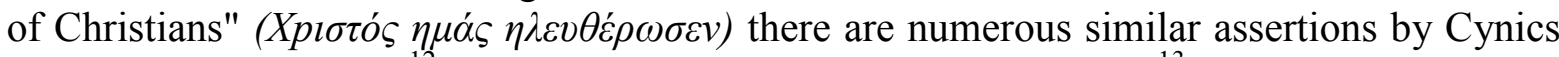
with regard to Diogenes ${ }^{12}$ and by Epicureans with regard to Epicurus ${ }^{13}$.

b. The discussion of sanctified meats in 1 Cor 8:1-11:1 presents two distinctive conceptions of freedom. In chap. 9 Paul argues that he is free from everyone because he does not accept money for his proclamation. Instead, by preaching free of charge he preserves his integrity and authority in the Gospel and can thus win more converts (1 Cor 9:19). Recent scholarship has recognized that the type of freedom Paul has here in mind, is precisely a conception of eleutheria also found in the Hellenistic tradition ${ }^{14}$. In other words, the Pauline freedom in 1 Cor 9 is not a gift of Christ or God but rather something Paul himself acquires by waiving financial support, even though he knows that Christ had commanded the opposite (1 Cor 9:14).

c. Only in 1 Cor 10:29 are we encountered with a freedom that is specifically Christian. Certain Corinthians maintained that they were free to eat sanctified meat (1 Cor

\footnotetext{
10 F. S. Jones, "Freiheit" in den Briefen des Apostels Paulus: Eine historische, exegetische undreligionsgeschichtliche Studie, GTA 34: Göttingen 1987.

${ }^{11}$ This idea was already clearly present in Euripides, e.g., Fr. 831 and was a standard starting point for Cynic and Stoic discussions of freedom, e.g., Bion in Stob. Flor. 3.2.38; Dio Chrys. Or. 14, 15; Epict. Diss. 4.1; that. 1 Cor 7:22 imagines (in juristically correct terminology).

${ }^{12}$ Cf. e.g., Crates Theb. Ep. 8; Lucian Vit. Auct. 8 etc.

${ }^{13}$ Cf. e.g., Cicero Tusc. 1.48; Lucian Alex. 47, 61 etc.

${ }^{14}$ Cf. e.g. the example of Socrates in Xen. Mem. 1.2.5-7, Ap. 16; also Muson. Fr. 11. The survival of this tradition at the time of Paul, and an entire treatise by Lucian, De mercede conductis potentium familiaribus [Eng title: "OnSalaried Posts in Great Houses"], is devoted precisely to the subject of loss of eleutheria through acceptance of a misthos.
} 
10:29) because Christian faith had convinced them that the gods of the gentiles do not exist (1 Cor 8:4). They thus considered themselves free, but free in contrast not to Jews but rather to gentiles (1 Cor 8:7). The background for this view of freedom is of course found also among Cynics, who were notorious for their indiscriminate eating habits connecting them with the term "freedom"15. But Saint Paul added here another dimension: this time the ecclesiological, one as he did in ch.7 with the Christological ("why should my freedom be subject to the judgment of someone else's conscience?" 1 Cor 10:29; cf. also 1 Cor 10:32 kai ti ekklisia tou theou, in addition to his argument in 1 Cor 8:9 "take care that this freedom of yours does not somehow become a stumbling block to the weak"). In other words, St Paul corrected a common understanding of freedom by introducing a completely different conception of the term ${ }^{16}$.

d. In 2 Cor 3:17 Paul again speaks positively of Christian freedom and introduces yet another Hellenistic tradition on the topic. Here eleutheria is equivalent to parrhesia or freedom to speak forthrightly, and without a veil, for where the Spirit dowels there is freedom $^{17}$.

e. The observation that none of these views of freedom has anything to do with the conventional schema "freedom from law, sin, and death" sheds new light on Paul's use of the concept of freedom in his letter to the Galatians. None can argue nowadays that Paul had preached "freedom from the law" in his initial proclamation to the Galatians (or to any of his other congregations). Such an understanding of eleutheria, as we have seen so far, is nowhere reflected in Paul's chronologically earlier letters. In addition, it should be noted that the phrase "freedom from the law" is nowhere mentioned in this letter. When Paul speaks of the upper Jerusalem as free in Gal 4:26, he rather meant free from corruption (cf. Rom 8:21); and in Gal 5:1 the freedom of the Christian includes at least also freedom from service to the elements. The rhetorical effect that Paul was trying to create by employing the term "freedom" is most apparent in the political imagery evoked in Gal 2:4f. Paul claims "freedom" for his version of the Gospel calling his opponents "spies and enemies of freedom ". Since his opponents' goal was to subject the free Christians "to themselves", it is clear that Paul was not operating here with the conventional concept of "freedom from the law." "Freedom" is more probably being employed in accordance with the classical Aristotelian standard definition as "freedom to do what one likes." within the framework.

f. This meaning fits Gal 5:13 ("do not let freedom be an excuse to the flesh"), where a clearly ecclesiological nuance is added ("let love make you serve one another"), for in this passage the condition of slavery is described as not being able to do what one wishes (Gal $5: 17)$.

g. This analysis brings us to the epitome of the Pauline thought, his letter to the Romans. In this letter, where most of the argument for an internalized understanding of freedom by Paul is based upon ${ }^{18}$, his employment of the notion of "freedom" is much more reserved than it was generally thought. Thus in Rom 6:18-22 all words of freedom are strikingly used in an absolutely neutral way to describe both Christian and non-Christian

\footnotetext{
${ }^{15}$ Cf. Porph. Abst. 1.42; and Diog. Laert. 6.73.

${ }^{16}$ Even though it was the Corinthians who introduced this Cynic concept of freedom, St Paul does not reject this new understanding of Christian faith but rather draws on other Hellenistic concepts of freedom known to him in order to promote a more holistic, and certainly not simply internalized, view of freedom.

${ }^{17} \mathrm{Cf}$. especially v 12 . Note that in Hellenistic writings the two words are frequently synonymous. See e.g. Lucian Demon. 3, Peregr. 18; Philo QuodOmn 95.

${ }^{18}$ Cf. "Having been set free from sin" (Rom 6:18); when you were slaves of sin, (v.20); now that you have been freed from $\sin (\mathrm{v} .21)$
} 
existence. Vv 6:18 and 22 ("having been freed from $\sin ^{\prime \prime}$ ) are counterbalanced by v 20 ("you were free with respect to righteousness"). Only in Rom 7:2-3 do we find the phrase "free from the law," but here the context strongly emphasizes the new bond of the Christian. Finally, Rom 8:21 transfers freedom totally into the future by reliance on an apocalyptic tradition (freedom from corruption; cf. Gal 4:26), expanding it to the cosmic realm ("the creation itself will be set free from its bondage to decay and will obtain the freedom of the glory of the children of God"). Some scholars believe that Paul's restraint and qualifications in his use of "freedom" in Romans is doubtless owing to his suspicion that the Romans had heard blasphemies of his teaching as libertine (Rom 3:8, 6:1, 15).

The rest of the N.T. evidence with regard to freedom either follow the Pauline reflection or provide a further elaboration of it, as it is clear in the Johannine connection of truth and freedom ("know the truth, and the truth will make you free" Jn 8:32).

\section{A SOCIO-HISTORICAL APPROACH}

In recent years social and anthropological science, and in particular "Cultural" or "Social" Anthropology gave new impetus to biblical research and unexpectedly shed new light to the understanding of the Christian origins. In my view, the affirmation of the importance of "common meals" (i.e. the Eucharist) in dealing with Christian identity was the result, to a certain extent, of recent developments in the field of "Cultural Anthropology". The combination of biblical and cultural anthropological studies has enormously contributed to the predominance within Christian circles, and to a certain degree in theological scholarship, of the assumption that the Eucharist determines the esse and the identity of the Church right from the beginning ${ }^{19}$.

Gillian Feeley-Harnik has convincingly shown that food was an important language in which Jews of the time of Jesus expressed relations among human beings and especially between human beings and God. Violation of dietary rules and inclusion in religious tables of non-Jews or unclean people became equivalent to apostasy ${ }^{20}$. The problem of who eats what with whom and why was of extreme importance, the anthropologists insist ${ }^{21}$, since "anyone familiar with Jewish religious observance will notice that food plays a considerable part throughout", as Jacob Neusner, a specialist in the field has stated ${ }^{22}$. It is rightly argued, that "what distinguished Jesus among many of his rabbinic contemporaries was his practice of fellowship at meals" ${ }^{23}$. J.G.D.Dunn argues that "open table fellowship" and the absence of boundaries at meals are "characteristic and distinctive of the social-self-understanding that Jesus encouraged in his disciples" 24 .

In the third millennium, therefore, one can fairly argue that biblical research has proved (with the help of other disciplines) beyond any doubt that Jesus' (and the early Church's thereafter) "open fellowship" and their "inclusive" theology constitutes a characteristic element of the Christian identity, which determined Pauline understanding of

\footnotetext{
${ }^{19}$ More on this in my "Eucharist as a Unifying and Inclusive Element in N.T. Ecclesiology,"

${ }^{20}$ G. Feeley-Harnik, The Lord's Table. Eucharist and Passover in Early Christianity, UPP: Philadeplia 1981, especially ch.4.

${ }^{21}$ Ibid, p. 6.

${ }^{22}$ J. Neusner, Invitation to Talmud: A Teaching Book, Harper and Row: New York, 1973, p. 18

23 B. Chilton, "Inclusion and Noninclusion: The Practice of the Kingdom in Formative Christianity," in J. Neusner (ed.), Religion and the Political Order, Scholars Press: Atlanta, 133-172, p. 137; also in his Pure Kingdom: Jesus' Vision of God, Eerdmans: Grand Rapids 1996.

${ }^{24}$ B. Chilton, "Inclusion and Noninclusion..., p. 599.
} 
freedom. For it was Saint Paul, first among all his co-apostles, who has so vigorously defended full and outright freedom in participation in the Church community's "common meals". He argued in favour of Peter's dining - before the arrival of James' people - with the Gentiles (Gal 2:12) in the so called "Antioch incident" 25 .

In addition, therefore, to the "literary/religio-historical" approach we presented in the first part, a "socio-historical" (or in traditional terms "eucharistic") approach to the Pauline data on freedom can equally enhance our understanding of the mind of the greatest figure in the history of the early Church. And to this end I suggest we start to analysis of the literary evidence the examination of the social and religious significance of the Jewish regulations about "cleanness". There is no doubt that the Historical Jesus has in numerous cases challenged the social and religious validity of some Torah regulations on clean and unclean. Most of his healings were directed toward people who were considered unclean: lepers (Mk. 1, 40-45, Mt. 8, 1-4, $\pi \rho \beta \lambda$. Lc. 17, 11-19), the woman in bloodshed (Mc. 5, 2534, Mt. 9, 20-22, Lc. 8, 43-48), people possessed by daemons, blind, cripple etc ${ }^{26}$.

The issue in question received quite dangerous consequences with the expansion of Christianity beyond the boundaries of Judaism, its mother religion. Receiving new converts was not an actual problem throughout the early Church. Even Judeo-Christians could accept and endorse it. The problem arose on the practical consequences of such a move: i.e. at the common Eucharistic (eschatological/messianic or otherwise) meals between former Jews and former Gentiles.

Till quite recently Saint Paul's letter to Galatians - especially its first autobiographical chapters - was almost exclusively read as an anti-authoritarian appeal, obviously because of the old confessional polemics. However, the so-called "Antioch incident" was an appeal to the "inclusive" character of the new religion, embracing all people of faith regardless of their past ${ }^{27}$. At the heart of the incident lies the problem of receiving former Gentiles and freely accepting them to the Eucharistic table without the Jewish legal conditions. Obviously in the early Church there were leaders insisting on separate Eucharistic celebrations, so that the basic rules of cleanness are kept. In other words they followed the line of a "Eucharistic exclusiveness". Paul's line, on the contrary, understood the fundamental issue of salvation "Eे $v \mathrm{X} \rho \iota \tau \omega$ " in a quite inclusive way, and understood as an inconceivable practice the separate Eucharistic tables. His view was that of a "Eucharistic inclusiveness ". For Paul there was no other way; any compromise would destroy the basis of his faith as freedom ${ }^{28}$. Therefore, he understood freedom, openness and inclusiveness in the Eucharistic meals as a way to open-up to, and advance toward, the nations. For Saint Paul

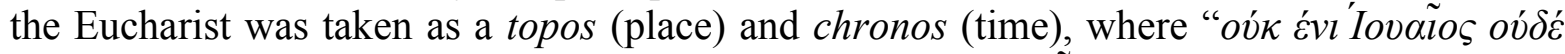

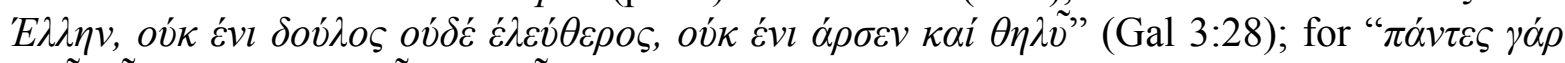

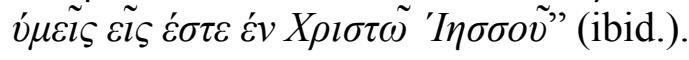

\footnotetext{
${ }^{25}$ More in D. Passakos, "Mexa TCOV eOvcov (jvvrjadiev.., Theology and Society in Dialogue”, Thessaloniki 2001, pp. $96 \mathrm{ff}$ (in Greek).

${ }^{26}$ B. J. Malina, New Testament World, pp. 143-146.

${ }^{27}$ F. Watson, Paul, Judaism and the Gentiles. A Sociological Approach, SNTSMS 56, Cambridge: CUP, 1986; S. Agouridis, "The Incident Between Peter and Paul in Antioch (Gal 2:11-21)," ABM n.s. 12 [1992], pp. 5-27; B.P.Stoyannos, The Apostolic Synod EE0SAI1 (C) vol. IH', Thessaloniki 1973; also his dissertation Peter in Paul, Thessaloniki, 1968 (all in Greek).

${ }^{28}$ Cf. J.D.G. Dunn, "The Incident," p. 23; S.G.Wilson, Luke and the Law, Cambridge: CUP, 1983, p. 70. D. K. Passakos, The Divine Eucharist in St. Paul's Mission. A Sociological Approach .(Doctoral Dissertation, Thessaloniki
} 
Despite the compromise adopted at the Apostolic Council, Saint Paul's conception of freedom remained a central element in all charismatic and visionary expressions of Christian life ${ }^{29}$. And it was this determination that made the "Apostle of freedom", Paul, also an "Apostle of the Nations".

\section{CONCLUSION}

You have probably noticed that my paper did not put the emphasis all would expect on the last phrase of the title, i.e. "in Christ", with the exception of few passing references to the Christological nuance Saint Paul gave to the concept of freedom did it deliberately, and I left it for the last part of my paper for two reasons: First in order to deal with Saint Paul's dynamic view of Christology together with the other important subject of the relation between Saint Paul and Jesus Christ; closely connected with this question is the issue I mentioned at the beginning of the de-radicalization by our great apostle of the kerygma of Jesus of Nazareth in quite a number of cases including freedom. The question frequently asked is: what happened and in less than a generation Jesus' programmatic proclamation (Luke 4: 1ff) of the new messianic era, which would also entail liberation, according to the Prophets (Is 61: 1ff etc), after his death on the cross disappeared or at least became marginal.

Without denying any question, the solution Paul offered to ancient society was not as radical and idealistic as the solution the Palestinian community experienced in their "common" or "no property" communal life (evidenced in the Synoptic tradition and Acts). Nevertheless, the "open fellowship" and the "common Eucharistic meals" Saint Paul so vigorously defended, was in fact a realistic solution ${ }^{30}$ that can be characterized as a "social integration" of the Church (as an eschatological charismatic community and proleptic manifestation of the Kingdom of God) into a declining world ${ }^{31}$. This realistic solution of Paul may not struggle to implement the social values of unconditional freedom, justice and equality at any cost. Rather it gave priority to the reality of the Kingdom of God within the present social order. In other words, Saint Paul's emphasis was not upon social transformation as such, but upon the formation of an ecclesial (Eucharistic) reality that inevitably would become the decisive element in creating a new social reality of freedom, justice and equality.

\section{BIBLIOGRAPHY}

[1] H. Schlier, "EXev6epia etc.", TDNT vol. 2 pp. 496-502.

[2] Largely but not exclusively; see R. Bultmann, Theology of the New Testament. 2 vols. Trans. K. Grobel. New York and London 1955 ,

[3] Cf. K. Stendahl, Paul among Jews and Gentiles, Philadelphia: Fortress, 1976.

[4] J. D. G. Dunn, The Theology of Paul the Apostle, Edinburgh: T. \& T. Clark, 1997, Grand Rapids: Eerdmans, 1998.

[5] More on this in A. F. Segal, Paul the Convert: The Apostolate and Apostasy of Saul the Pharisee, New Haven: Yale University Press, 1990.

[6] See among many H. D. Betz, Paul's Concept of Freedom in the Context of Hellenistic Discussions about the Possibilities of Human Freedom. Protocol Series of the Colloquies of the Center for Hermeneutical Studies in Hellenistic and Modern Culture 26. Berkeley 1977.

[7] Cicero Off. 1.70; Epict. Diss. 4.1.1; Dio Chrysostom, Orla 14. 13, 17 etc.

${ }^{29}$ J. D. G. Dunn, Jesus Remembered, Eerdmans: Grand Rapids 2003, p. 599.

${ }^{30}$ For another view on the problem, see N. A. Dahl, "Paul and Possessions" in Studies in Paul, pp.22-39.

${ }^{31}$ Cf. Paul (Thessaloniki 2005, in Greek), p. 243. 
[8] F. S. Jones, "Freiheit" in den Briefen des Apostels Paulus: Eine historische, exegetische undreligionsgeschichtliche Studie, GTA 34: Göttingen 1987.

[9] Demon. 3, Peregr. 18; Philo QuodOmn 95.

[10] J. Neusner, Invitation to Talmud: A Teaching Book, Harper and Row: New York, 1973, p. 18.

[11] B. Chilton, "Inclusion and Noninclusion: The Practice of the Kingdom in Formative Christianity," in J. Neusner (ed.), Religion and the Political Order, Scholars Press: Atlanta, 133-172, p. 137; also in his Pure Kingdom: Jesus' Vision of God, Eerdmans: Grand Rapids 1996.

[12] More in D. Passakos, "Mexa TCOV, "Theology and Society in Dialogue, Thessaloniki 2001, pp. 96ff, in Greek.

[13] F. Watson, Paul, Judaism and the Gentiles. A Sociological Approach, SNTSMS 56, Cambridge: CUP, 1986; S.

[14] Agouridis, "The Incident Between Peter and Paul in Antioch (Gal 2:11-21)," ABM n.s. 12 [1992], pp. 5-27;

[15]B.P.Stoyannos, The Apostolic Synod EE0SAI1C vol. IH', Thessaloniki 1973; also his dissertation Peter in Paul, Thessaloniki, 1968 (all in Greek).

[16] J.D.G. Dunn, "The Incident," p. 23; S.G.Wilson, Luke and the Law, Cambridge: CUP, 1983, p. 70 . D. K.

[17] J. D. G. Dunn, Jesus Remembered, Eerdmans: Grand Rapids 2003, p. 599.

[18] N. A. Dahl, "Paul and Possessions" in Studies in Paul, pp. 22-39. 